\title{
Zmarnowana szansa. Łukasz Krzyżanowski, Dom, którego nie było. Powroty ocalałych do powojennego miasta, Wołowiec 2016, Wydawnictwo Czarne, ss. 376
}

Łukasz Krzyżanowski pracował nad swoją książką szereg lat. Można było spodziewać się dzieła ważnego, a nawet wybitnego. Dom, którego nie byto zaczyna się w tonacji osobistej. „Na początku drogi, którą przebyłem, przygotowując tę ksiażkę, leży okrutna zbrodnia. W 2008 roku zostałem zatrudniony przez Instytut Socjologii Uniwersytetu Jagiellońskiego do uporządkowania materiałów pozostałych po zmarłym profesorze Andrzeju Paluchu. Podczas tej pracy natrafiłem na lakoniczną wzmiankę o dwóch Żydówkach - matce i córce. Kobiety przetrwały Zagładę na podkarpackiej wsi. Tuż po wojnie wróciły do swojej rodzinnej miejscowości. Tam nieznani z imienia i nazwiska Polacy wyprowadzili je "za górkę», zgwałcili i zamordowali. Gdy czytałem tę historię, nie interesowali mnie sprawcy ani motywy tej odrażajacej zbrodni. Moją uwagę całkowicie pochłonęły tragedia i niewyobrażalne cierpienie dwóch kobiet oraz fakt, że nigdy nie dowiemy się, kim były i jak wyglądało ich życie. Dziś nie mają nawet imion" (s. 21). Kolejnym impulsem okazał się dla Krzyżanowskiego film Jana Jakuba Kolskiego, pt. Pogrzeb kartofla z 1990 r., o powrocie do domu więźnia z obozu koncentracyjnego, który nie odnajduje już bliskich, spotyka się z wrogością sąsiadów, którzy rozkradli jego dobytek, uznając za zmarłego (s. 21-22).

Podążając tymi tropami, Krzyżanowski postanowił uczynić tematem swojej rozprawy doktorskiej, będącej podstawą omawianej tu książki, „losy Żydów, którzy wrócili lub próbowali wrócić do swoich rodzinnych miejscowości tuż po wyzwoleniu" (s. 22). Uwagę skupił na Radomiu, z którego sam pochodzi. 
Autobiograficznych wtrętów z czasem przybywa; dowiadujemy się, gdzie Autor mieszkał, do jakiej szkoły chodził, a nawet i o tym, że nie jest religijny, co ponoć miało mu pomóc w uzyskiwaniu wywiadów (s. 30). Dzięki temu relacja między historia a historykiem staje się tu bardziej bezpośrednia. Co więcej, książka nabiera cech reportażu historycznego - odkrywanie przeszłości i tożsamości środowiska, w którym Autorowi przyszło dorastać.

Zebrane przez Łukasza Krzyżanowskiego źródła zachęcają do lektury. Z jednej strony sa to akta Okręgowego Komitetu Żydowskiego (OKŻ) w Radomiu z lat 1945-1950, zachowane szczęśliwym zbiegiem okoliczności, z drugiej - przeprowadzone przez Autora wywiady biograficzne z Żydami i osobami nieżydowskiego pochodzenia, które tuż po wojnie przebywały w Radomiu lub posiadały związki z tym miastem. Szereg ważnych źródeł udało się znaleźć w zbiorach instytucji zagranicznych: Muzeum Holokaustu w Waszyngtonie, Żydowskiego Instytutu Naukowego oraz American Jewish Joint Distribution Committee Archives w Nowym Jorku, w Clara Thomas Archives and Special Collections na York University w Toronto oraz archiwum Instytutu Yad Vashem w Jerozolimie. Kwerenda archiwalna została zatem zakrojona na szeroką skalę i można by sądzić, że Autor nie pominął żadnego istotnego dokumentu. Mocno wybrzmiewa deklaracja, że książka „jest próbą zrozumienia ludzkiego losu z całą jego złożonością w konkretnych społeczno-historycznych warunkach" (s. 26).

Do lektury książki zachęca spis treści zapowiadający klarowną kompozycję. Krzyżanowski podzielił prace na cztery części zatytułowane: „Miasto”, „Przemoc”, „Społeczność”, „Mienie”. Praca poprzedzona została obszernym wstępem, wieńczy ją zakończenie i epilog. Części książki Autor podzielił na podrozdziały, które, niestety, nie zostały wyszczególnione w spisie treści. Dopiero po przeczytaniu, a przynajmniej uważnym przejrzeniu książki możemy zorientować się w pełni w jej strukturze.

Sporo uwagi Krzyżanowski poświęcił doprecyzowaniu terminologii, która się posługuje. Przykładem „wyzwolenie”. Jak pisze, „niektórych czytelników może dziwić, że moment zakończenia okupacji niemieckiej nazywam wyzwoleniem. Jestem świadomy kontrowersji, jakie istnieją wokół użycia tego terminu $\mathrm{w}$ odniesieniu do sytuacji ziem polskich tuż po zakończeniu II wojny światowej. Pisząc o wyzwoleniu, nie zajmuję jakiegokolwiek stanowiska w historycznych i politycznych sporach z zakresu najnowszej historii Polski. Użycie tego terminu wynika z faktu, że dla Żydów wyjętych spod prawa przez nazistów zakończenie okupacji niemieckiej położyło kres życiu w nieustannym zagrożeniu systematyczną eksterminacją. Było więc prawdziwym wyzwoleniem i tak, przynajmniej w pierwszych chwilach, postrzegało je bardzo wielu ocalałych" (s. 27). To ważna uwaga pozwalająca zrozumieć odmienna perspektywę Żydów i Polaków.

Najważniejsze są tu słowa „ocalały” i „ocalała”. Krzyżanowski wskazuje, że w przyjętej przezeń terminologii „ocalałym lub ocalała jest każdy, kto był 
narażony na represje $\mathrm{w}$ związku $\mathrm{z}$ uznaniem go przez nazistowskie prawo rasowe za «Żyda» i komu mimo to udało się przeżyć. Dlatego terminy «ocalały» i Żyd traktuję zamiennie" (s. 26). Co za tym idzie, Autor zrezygnował z terminów „ocalony”, „ocalona”, „ocaleni”. Wyjaśnia dalej, że zamiany tej dokonał pod wpływem Joanny Tokarskiej-Bakir, wedle której określenie „ocaleni” „uprzedmiotawia tych, którzy przeżyli, odbiera im sprawczość, gdy tymczasem ratowanie się często wymagało podjęcia świadomej decyzji i trwania w niej” (s. 26). A zatem w książce Krzyżanowskiego nie ma „ocalonych”, sa tylko „ocalali”. Ta lingwistyczna zmiana niesie poważne konsekwencje: z pola widzenia znikają ci, którzy pomogli Żydom w przetrwaniu. Krzyżanowski okazuje się tu konsekwentny: o pomocy udzielanej ukrywającym się Żydom przez Polaków z jego książki właściwie niczego się nie dowiemy. Tymczasem inne badania pokazuja, że trzy czwarte Żydów, które przeżyło w okupowanej przez Niemców Europie, przetrwało dzięki pomocy innych ${ }^{1}$. Nieobecny w książce Krzyżanowskiego Władysław Bartoszewski oceniał, że takiej czy innej pomocy Żydom udzieliło „co najmniej kilkaset tysięcy Polaków różnej płci i wieku"2. Czy godzi się o nich nie pamiętać?

Lekturze wstępu do książki towarzyszy zaciekawienie metodą badawcza Krzyżanowskiego, które przeradza się jednak w zdziwienie, gdy dochodzimy do literatury przedmiotu, a zarazem intelektualnych przewodników Krzyżanowskiego. Wskazanie na badania Ireny Hurwic-Nowakowskiej, której książkę Żydzi polscy (1947-1950) można już uznać za klasyczna, wydaje się dość oczywiste. Dalej Krzyżanowski wspomina krótko o pracach Krystyny Kersten, Dariusza Stoli, Bożeny Szaynok, Zygmunta Baumana. Z przypisów wynika, że ma na uwadze także badania Aliny Skibińskiej, Barbary Engelking, Jana Grabowskiego, Augusta Grabskiego, Dariusza Libionki, Natalii Aleksiun, Andrzeja Żbikowskiego. Jednak we wstępie nie wspomina Sebastiana Piątkowskiego, autora książki Dni życia, dni śmierci. Ludność żydowska w Radomiu w latach 1918-1950, choć w dalszych częściach swojej pracy Krzyżanowski czerpie od niego dość dużo informacji.

Za „niewątpliwy przełom” w badaniach i postrzeganiu losów „ocalałych z Zagłady" Krzyżanowski uznaje twórczość Jana Tomasza Grossa, szczególnie jego książkę pt. Strach. Antysemityzm w Polsce tuż po wojnie. Historia moralnej zapaści. Owszem, Krzyżanowski przywołuje dwa głosy nieco dystansujące się wobec Grossa - Pawła Machcewicza i Marcina Zaremby ${ }^{3}$. Zastrzeżenia

${ }_{1}^{1}$ R.C. Lucas, Zapomniany Holokaust. Polacy pod okupacja niemiecka 1939-1944, przedm. N. Davies, tłum. S. Stodulski, wyd. 2, Poznań 2017, s. 241.

${ }^{2}$ W. Bartoszewski, Po obu stronach muru, w: Ten jest z ojczyzny mojej. Polacy z pomoca Żydom 1939-1945, oprac. W. Bartoszewski, Z. Lewinówna, wyd. 3, Warszawa 2007, s. 53.

${ }^{3}$ W przypisie 42 (s. 363) Krzyżanowski wspomina jeszcze o tomie Wokót Strachu. Dyskusja o ksiażce Jana T. Grossa, wybór i układ tekstów M. Gądek, Kraków 2008. Z kolei zbiór polemik z Grossem, opublikowany w tomie pt. Cena „Strachu”. Gross w oczach historyków. Wybór publicystyki (red. R. Jankowski, Warszawa 2008), Krzyżanowski dezawuuje 
Machcewicza co do „radykalizmu interpretacji” Grossa Krzyżanowski oddala, posiłkując się opinią Jerzego Jedlickiego w obronie Grossa o niemożności rezygnacji z sądów wartościujących w opisie następstw Zagłady. W przypadku Zaremby Krzyżanowski podkreśla, że jego książka Wielka trwoga. Polska 1944-1947. Ludowa reakcja na kryzys - wedle deklaracji samego autora - nie była polemika z tezami autora Strachu, a raczej uzupełnieniem rozważań Grossa nad przyczynami powojennej przemocy antyżydowskiej „o refleksję nad kondycja psychiczną i materialną sprawców, czyli Polaków" (s. 35).

To kolejna istotna zmiana lingwistyczna, tym razem podsunięta niepostrzeżenie. Polacy to już nie ofiary II wojny światowej i narzuconego następnie komunistycznego totalitaryzmu, lecz „sprawcy”. Ta coraz częściej spotykana w ostatnich latach ewolucja paradygmatu (Niemcy jako „naziści”, Polacy jako „sprawcy”) znajduje odbicie również w książce Krzyżanowskiego.

Publikacje Grossa, zwłaszcza jego Strach i Złote żniwa, okazuja się najważniejszym dla Krzyżanowskiego punktem odniesienia. W książce liczącej 370 stron Gross przywoływany jest $71 \mathrm{razy}^{4}$. Dla porównania Zaremba 40 razy, Aleksiun i Skibińska - po 11 razy, Stola i Żbikowski - po 7 razy, Kersten - 6 razy, Machcewicz - 5 razy. Dość szybko można się zorientować, że interpretacje i uogólnienia poczynione zostały w większości pod wpływem Grossa, co najwyżej uzupełnianego przez pozostającego w nim w zgodzie wedle Krzyżanowskiego - Zarembę. Książka, wychodząc od przedstawienia losów „ocalałych”, grawituje ku opisowi (czy powtórzeniu przejętych od Grossa opisów) antyżydowskiej przemocy Polaków po wojnie oraz uwłaszczenia się Polaków na pożydowskim mieniu.

W tym ostatnim wypadku przewodnikiem intelektualnym Krzyżanowskiego okazuje się Andrzej Leder i jego książka pt. Prześniona rewolucja. Ćwiczenia z logiki historycznej, która ma być jakoby „traktatem społeczno-filozoficznym” przynoszącym „refleksję nad genezą współczesnego społeczeństwa polskiego” (s. 41).

Tu trzeba na chwilę się zatrzymać. Patrzac z perspektywy czterech już lat, które minęły od publikacji Prześnionej rewolucji, należy uznać za porażkę historyków, że nie poddali owego „traktatu” krytycznej recenzji. W rezultacie zaczał on funkcjonować, jak widać w książce Krzyżanowskiego, jako przenikliwa diagnoza. „Traktat społeczno-filozoficzny” Ledera - inkrustowany terminologia przejęta od Jacques'a Lacana, Benjamina Waltera czy Slavoja Žižka - przyniósł tymczasem tezy mające na celu gruntowną redefinicję polskiej historii najnowszej wraz z postulatem dekonstrukcji polskiej tożsamości. Przyjrzyjmy się im pokrótce. Po pierwsze, wbrew temu, co uważano do tej pory, Polacy okazali się w istocie beneficjentami II wojny światowej

stwierdzeniem, że to „teksty prawicowych historyków i publicystów” wydane przez „konserwatywny i ultrakatolicki kwartalnik "Fronda»", co (w domyśle) ma zwalniać z lektury. W innych przypadkach tego rodzaju kwalifikacji politycznych Krzyżanowski nie stosuje.

${ }^{4}$ Skali cytowań nie oddaje indeks nazwisk, pomija on bowiem przypisy. 
jako „rewolucji przeprowadzonej przez Rosjan i Niemców”, której jednak nie zauważyli zaślepieni wizją samych siebie jako ofiary. Nie dostrzegli zatem, że oto dokonała się „rewolucja polskiego podmiotu”. A zatem Polacy byli podmiotem II wojny światowej, a nie przedmiotem, jak dotąd się wydawało. Po drugie, „geneza polskiej klasy średniej” ma swoje źródło w grabieży mienia żydowskiego, dokonanej w czasie i po wojnie. Gdyby ktoś zapytał o sensowność owej sugestii w odniesieniu do zrównanej z ziemią Warszawy (największego skupiska Żydów przed wojna) czy utraconych Kresów Wschodnich wraz z Wilnem, Lwowem, Pińskiem, Łuckiem i innymi ośrodkami, w których Żydzi stanowili znacząca, a nierzadko większościowa społeczność, oraz o realność „klasy średniej” w PRL (niemal całkowita likwidacja prywatnej przedsiębiorczości), Leder odpowiada na wszelki wypadek, że „oczywiście owa genealogia rzadko jest wypowiadana”, gdyż „ten ogromny fragment polskiej rewolucji pozostaje zapomniany, zaprzeczony, przemilczany”6. Mało tego, owa „prześniona rewolucja” była ,jednocześnie spełnieniem okrutnych pragnień. Temu spełnieniu towarzyszyła mściwa satysfakcja i - często dramatyczny - lęk" (w domyśle: lęk przed ujawnieniem, co czyni teraz Leder) ${ }^{7}$. Po trzecie, instalowanie dyktatury komunistycznej było wedle Ledera wojna domową ${ }^{8}$ czy raczej „chłopską wojną o charakterze klasowym”, w każdym razie wojną domową „na masową skalę”, która zakończyła się w 1947 r. $^{10}$ albo, jak czytamy w innym miejscu, trwała do $1948 \mathrm{r} .{ }^{11}$ Nie jest wprawdzie całkiem jasne w wywodzie Ledera, kto toczył tę wojnę domowa; jak wynika z kontekstu - chyba chłopi z obszarnikami o reformę rolna. Tak czy inaczej chłopskość wojny domowej sprawiła, że nie udało się ziścić marzenia o „proletariackim polu symbolicznym” - marzenia przywoływanego Mao Zedonga ${ }^{12}$. W ogóle chłopskość jako czynnik rewolucyjny jest podejrzana, bo przecież już „strajki chłopskie lat 20.” (bliżej nieznane historykom) „osunęły się w pogromy, takie jak w Przytyku" (zginęło tu, dodajmy, dwoje Żydów i jeden Polak) ${ }^{13}$. A w czasie wojny i po niej chłopi dopuszczali się czynów jeszcze gorszych. Po czwarte, wbrew pozorom PRL nie była dyktatura komunistyczna. Do $1968 \mathrm{r}$. „komuniści z Gomułką na czele ograniczali jeszcze wpływ Kościoła i tradycji nacjonalistycznej, ale nie mieli już siły ani chęci, by narzucić sowiecki model kultury "proletariackiej»”14. Tak więc „rok 1968 czy w ogóle późne lata 60.

\footnotetext{
${ }^{5}$ A. Leder, Prześniona rewolucja. Ćwiczenie z logiki historycznej, Warszawa 2014, s. 76.

${ }^{6}$ Ibidem, s. 90.

${ }^{7}$ Ibidem, s. 89-90.

8 Ibidem, s. 10, 157, 200.

${ }^{9}$ Ibidem, s. 109.

10 Ibidem, s. 159.

11 Ibidem, s. 200.

12 Ibidem, s. 112, 114.

13 Ibidem, s. 113.

${ }^{14}$ Ibidem, s. 191.
} 
i początek lat 70. niszczą formację liberalna, która tworzyła klimat po 1956 r. i na początku lat 60., i przywracają oraz ustanawiają jako dominujący narodowo-socjalistyczno-katolicki kompromis”"15. Uwaga: „przywracaja”! Czyli status quo sprzed 1956 r., bo przecież, jak uznał w ślad za Henrykiem Słabkiem Leder, w drugiej połowie lat czterdziestych XX w. Kościół z jednej strony stał się „skrajny, nacechowany wojowniczościa i integryzmem”, z drugiej - skłaniał się do „ideologicznej kolaboracji”"6. A zatem PRL nie była dyktatura komunistyczna (nie wspominając o totalitaryzmie), lecz dyktatura „narodowo-socjalistyczno-katolicka”; w skrócie można by zatem powiedzieć: nazistowsko-katolicka. Co za tym idzie, rewolucyjnie zapowiadajacca się na przełomie 1944 i $1945 \mathrm{r}$. epoka została zdominowana z jednej strony przez Kościół katolicki, z drugiej - przez wywodzącą się z chłopstwa nową klasę średnią uwłaszczoną na mieniu żydowskim. Wszyscy zaś wyparli ze świadomości to, że w istocie stanowią brudną wspólnotę złodziei, którzy dzięki II wojnie światowej wygrali los na loterii. Po piąte, pokłosiem tego stanu rzeczy jest to, że „pierwotna nienawiść do przepełnionych dobrymi intencjami inteligentów przetrwała w postaci wściekłości dzisiejszych «ludzi zbędnych», dzieci i wnuków przemieszczonego chłopstwa, kiboli, na politycznych i kulturowych przedstawicieli klasy średniej” (nota bene nieco wcześniej Leder sugerował, że klasa średnia to w istocie uwłaszczone chłopstwo, tu z kolei owa klasa średnia jawi się jako osobna kasta osaczona przez chłopstwo i kiboli) ${ }^{17}$.

Powinniśmy więc zawstydzić się, że jesteśmy Polakami. Ale sytuacja nie wygląda beznadziejnie. Ratunek można znaleźć w internacjonalizmie, który nie został dotychczas urzeczywistniony wskutek ,narodowo-socjalistyczno-katolickiego" dyktatu. Tak jak uczynili sami Lederowie. Bo przecież Andrzej Leder nie wymyślił tego wszystkiego bezinteresownie. Jego dziadkowie wraz z licznymi rodzinami zaczynali karierę jeszcze w SDKPiL, przeciwnej odzyskaniu przez Polskę niepodległości. Ojciec Andrzeja Ledera Władysław i jego stryj Stefan kontynuowali tę „działalność przy odbudowie i przekształcaniu odrodzonej Polski" po II wojnie światowej w LWP oraz w PPR/PZPR ${ }^{18}$. Doprawdy, aż trudno uwierzyć, że rzecz tak intelektualnie miałka, fałszująca historię, a przy tym przesycona ksenofobiczną pogardą dla ubogiego polskiego chłopstwa oraz antykatolicka idiosynkrazją została tu i ówdzie okrzyknięta jako ożywcza i nowatorska. Nie warto by o niej wspominać, gdyby w porę doczekała się krytycznej recenzji - i gdyby nie stała się jako „traktat społeczno-filozoficzny" jednym z najważniejszych, obok twórczości Jana Tomasza Grossa, punktów odniesienia dla Łukasza Krzyżanowskiego.

\footnotetext{
15 Ibidem, s. 192.

${ }^{16}$ Ibidem, s. 153.

17 Ibidem, s. 107.

${ }^{18}$ S. i W. Lederowie, Czerwona nić. Ze wspomnień i prac rodziny Lederów, Warszawa 2005, s. 24.
} 
Próżno by natomiast szukać w książce Krzyżanowskiego odniesień do wielu, zdawałoby się, podstawowych prac historyków. Zadania nie ułatwia brak bibliografii, niemniej i tak można ułożyć listę nieobecności: Władysław Bartoszewski, Michael Chęciński, Marek J. Chodakiewicz, Stanisław Ciesielski, Norman Davies, Piotr Gontarczyk, Krzysztof Jasiewicz, Łukasz Kamiński ${ }^{19}$, Ewa Kurek, Barnett Litvinoff, Richard C. Lucas, Andrzej Paczkowski²0, Antony Polonsky, Teresa Prekerowa, Timothy Snyder, Tomasz Strzembosz, Tomasz Szarota, Krzysztof Szwagrzyk, Marek Wierzbicki, Jan Żaryn... Nie ma odniesień do ważnego tomu Polacy i Żydzi pod okupacja niemiecka 1939-1945. Studia i materiaty, pod redakcja Andrzeja Żbikowskiego oraz wspomnianego już zbioru relacji Ten jest $z$ ojczyzny mojej. W opisie podziemia antykomunistycznego brakuje Atlasu polskiego podziemia niepodlegtościowego. Nasuwa się niepokojący wniosek, że Krzyżanowski pominą bodajże wszystkich badaczy, których ustalenia czy interpretacje w jakikolwiek sposób zakłóciłyby obraz relacji polsko-żydowskich przejęty głównie od Grossa. Nie byłby to może poważny zarzut, gdyby Autor ograniczył swoją refleksję tylko do Radomia. Doświadczenie radomskie stara się jednak zuniwersalizować (w tytule nie ma wszak Radomia), wielokrotnie przywołuje też przykłady z innych obszarów Polski, co nakazywałoby poszerzenie literatury przedmiotu.

Część I Domu, którego nie byto przynosi początkowo interesujący obraz województwa kieleckiego i samego Radomia przed wojną. Pokrótce Krzyżanowski informuje, że Radom stał się ważnym ośrodkiem Centralnego Okręgu Przemysłowego, głównie za sprawą lokalizacji tu zakładów zbrojeniowych. Zaciekawia portret socjologiczny i demograficzny miasta. Okazuje się, że spośród 90 tys. mieszkańców Radomia w 1938 r. jedną trzecią stanowili Żydzi. Jak wyjaśnia Krzyżanowski, „mieszkali oni w różnych częściach Radomia, lecz ich życie religijne i polityczne koncentrowało się w centrum, gdzie znajdowała się dzielnica żydowska" (s. 47). Ważna wydaje się uwaga, że grupa Żydów zasymilowanych była „stosunkowo nieliczna”, zdecydowana większość zaś posługiwała się jidysz i - jak niejasno wyraża się Autor - „podtrzymywała związek z tradycją i religią żydowską" (s. 47). Niejasność tę potęguje sformułowana nieco dalej konstatacja, że to Żydowska Gmina Wyznaniowa była „najważniejszą instytucją żydowską” w Radomiu, co wskazywałoby na to, że tradycja i religia stanowiły tu raczej istotę żydowskiej tożsamości, a zatem chodziło o coś więcej niż tylko „podtrzymywanie związku” (s. 49). Istotna jest informacja, że „bardzo niewielu Żydów” zajmowało stanowiska urzędnicze, za to byli oni „licznie reprezentowani wśród przedstawicieli wolnych zawodów" (np. stanowili połowę lekarzy i stomatologów) (s. 48). Żydzi odgrywali też pewną rolę $\mathrm{w}$ życiu politycznym miasta, reprezentowani byli w Radzie Miejskiej Radomia, którą rządziła PPS.

19 Przywołany raz jako współredaktor tomu.

${ }^{20}$ Przywołany raz jako współredaktor tomu. 
Nie dowiemy się natomiast z książki Krzyżanowskiego o roli Żydów $\mathrm{w}$ gospodarce miasta, zwłaszcza $\mathrm{w}$ handlu, rzemiośle i przemyśle, a chyba nie była ona mała, co wynika choćby z opisu sporów o żydowskie garbarnie (s. 52). Krzyżanowski skupia głównie uwagę na nierównościach, przy czym można by dyskutować, czy najlepsze źródło do ich poznania stanowią przytaczane przez Autora postulaty formułowane przez radnych żydowskich ugrupowań socjalistycznych (s. 50). Musimy też wierzyć Autorowi na słowo, gdy czytamy - w oparciu o jednostronny przekaz - o „wzroście nastrojów nacjonalistycznych i antysemickich wśród chrześcijańskiej ludności miasta" $\left(\right.$ s. 51) ${ }^{21}$. Nie jest też jasne, na czym miał polegać pogrom 6 V 1931 r., wspomniany przez Krzyżanowskiego w kontekście konfliktów kibiców drużyn sportowych (s. 51). Generalnie Autor jest przekonany, że „dystans między społecznościami zamieszkującymi Radom w okresie międzywojennym się pogłębiał”, a „uległ jeszcze pogłębieniu w czasie okupacji niemieckiej” (s. 55).

W obrazie okupowanego Radomia zabrakło kluczowego, zdawałoby się, elementu: Gestapo. Co najwyżej pojawiaja się wzmianki o gestapowcach $\mathrm{w}$ przytaczanych relacjach, potem jeszcze $\mathrm{w}$ kontekście powojennego procesu SS-Obersturmbannführera Wilhelma Bluma, likwidatora radomskiego getta (s. 60, 237) ${ }^{22}$. Nie ma tu zatem Paula Fuchsa, dzięki któremu radomskie Gestapo stało się głównym ośrodkiem rozpracowywania i niszczenia Polskiego Państwa Podziemnego (PPP), co nie mogło przecież nie mieć wpływu na polską społeczność Radomia. Po wymazaniu z obrazu Radomia tego elementu Krzyżanowskiemu łatwo przychodzi konstatacja, że „pomoc Żydom ze strony nieżydowskich mieszkańców Radomia w czasie Zagłady nie tylko nie miała masowego charakteru, ale w ogóle była zjawiskiem stosunkowo rzadkim" (s. 68).

Stopniowo akcent przesuwa się w tym właśnie kierunku: mniej czytamy o cierpieniach Żydów wywożonych do obozów zagłady, a coraz więcej o negatywnych postawach Polaków. Towarzyszy temu relatywizowanie okupacyjnego doświadczenia Polaków. Jak przekonuje Krzyżanowski, „nieżydowscy Polacy, chociaż prześladowani przez niemieckiego okupanta, znaleźli się w pozycji uprzywilejowanej w stosunku do swoich żydowskich współobywateli” (s. 69). Cóż, osobliwe to przywileje. Zrujnowana Warszawa wskutek morderczych

${ }^{21}$ Dla skomplikowania obrazu można by dodać, że w Radomiu i okręgu radomskim (zwłaszcza w Opocznie i Końskich) znaczące wpływy, sięgające początku XX w., miało Stronnictwo Narodowe (SN). Mimo poparcia ludności nie uczestniczyło jednak we władzy. W latach trzydziestych XX w. czterech tutejszych działaczy SN było więzionych w Berezie Kartuskiej. W 1936 r. zorganizowana przez SN demonstracja chłopów z Odrzywołu w związu z bojkotem wyborów została ostrzelana przez policję z karabinów maszynowych. Niemal całe przedwojenne kierownictwo okręgu radomskiego SN rozbito jesienią 1939 r. (aresztowania, wywózki do obozów koncentracyjnych, emigracja). Archiwum Instytutu Pamięci Narodowej, 00231/152/1, Okręg Radomski SN. Relacja Władysława Jaworskiego spisana podczas odbywania kary więzienia, ok. X 1955, k. 213-215, 226.

22 Jako ciekawostkę można tu dodać, że Blum nie doczekał się dotąd biogramu w niemieckiej Wikipedii. 
nalotów we wrześniu 1939 r., Intelligenzaktion, Außerordentliche Befriedungsaktion, łapanki i egzekucje uliczne, masowe wywózki do niewolniczej pracy, obozy koncentracyjne, akcje wysiedleńcze (symbolem Gdynia, a zwłaszcza Zamojszczyzna) wymierzone w ok. 2 mln Polaków, eksterminacja duchowieństwa katolickiego, hekatomba Powstania Warszawskiego. To z jednej strony, a z drugiej: eksterminacyjna operacja polska NKWD z lat 1937-1938, aresztowania i deportacje na Syberię w latach 1939-1941, Katyń, rzeź wołyńska, potem masakra podziemia niepodległościowego (symboliczna obława augustowska), eksterminacja polskich patriotów przez NKWD do spółki z UB. O żadnym z tych kontekstów w książce Krzyżanowskiego nie ma choćby wzmianki.

O tym, że II wojna światowa pochłonęła ok. 2,8 mln Polaków (przyjmując kryteria etniczne), z książki Krzyżanowskiego też się nie dowiemy ${ }^{23}$. Warto przypomnieć, że już wiele lat temu Teresa Prekerowa zwracała uwagę, iż „w ciagu pierwszego roku okupacji, a nawet dłużej, ludność polska nie miała wrażenia, że Żydzi sa bardziej uciskani od niej. Wprost przeciwnie. To przecież głównie Polacy byli aresztowani, torturowani w więzieniach Gestapo, rozstrzeliwani, zsyłani do obozów koncentracyjnych w Oświęcimiu, Buchenwaldzie czy Sachsenhausen. Żydów bardziej ograniczano pod względem ekonomicznym, odsuwano coraz ostrzej od udziału w życiu gospodarczym kraju, ale większość ludności polskiej uważała to za mniejsze zło"24. Szymon Datner szacował, że „w latach 1939-1941 stosunek mordowanych Polaków do mordowanych Żydów kształtował się jak 10 : 1" (w latach 1942-1943, po rozpoczęciu systematycznej zagłady Żydów, wynosił już $2: 3)^{25}$. Przy czym Datner nie brał pod uwage zbrodni popełnionych na Polakach pod okupacja sowiecka.

Brak kontekstów historycznych i niuansów chronologicznych powoduje zniekształcenie obrazu. Na poparcie tezy o grabieżczych skłonnościach „ludności polskiej” Krzyżanowski przywołuje zapiski z dziennika Zygmunta Klukowskiego z kwietnia i października 1942 r. o chłopach przejmujących „nędzny żydowski dobytek” czy „towary z małych żydowskich sklepików”. To prawda, Klukowski opisał te zachowania jako „skandaliczne” i „bezwstydne”. Można by tu dodać jeszcze jego zapiski o udziale polskich policjantów „granatowych" w egzekucjach ${ }^{26}$. Tyle że to obraz niepełny, a i tak jeszcze przez Krzyżanowskiego zniekształcony.

Dla przykładu z zapisku Klukowskiego z 13 IV 1942 r. (zresztą bez podania dokładnej daty) Krzyżanowski przytoczył następujący fragment: „zjechało się

${ }^{23}$ Do tego należy dodać ok. 200 tys. ofiar operacji polskiej NKWD.

${ }_{24}$ T. Prekerowa, Wojna i okupacja, w: Najnowsze dzieje Żydów w Polsce $w$ zarysie (do 1950 roku), red. J. Tomaszewski, Warszawa 1993, s. 304-305. Zob. też: R.C. Lucas, op. cit., s. 220-221.

${ }^{25}$ Sz. Datner, Las Sprawiedliwych. Polacy zamordowani przez Niemców za niesienie pomocy Żydom, Warszawa 2013, s. 5.

${ }^{26}$ Zob. np.: Z. Klukowski, Zamojszczyzna, t. I: 1918-1943, Warszawa 2007, s. 274, zapisek z 7 V 1942. 
sporo furmanek ze wsi i wszystko to niemal cały dzień stało w oczekiwaniu, kiedy będzie można przystapić do rabunku. $\mathrm{Z}$ różnych stron dochodzą wiadomości o skandalicznym zachowaniu się części ludności polskiej i rabowaniu opuszczonych żydowskich mieszkań. Pod tym względem nasze miasteczko z pewnością nie pozostanie w tyle". Krzyżanowski ucią jednak pierwsze słowa tego zapisku: „Na miasto wyległy wszystkie szumowiny”. A zatem nie „ludność polska”, lecz „szumowiny” i „część ludności polskiej”27. Zapisek z 13 IV 1942 ma też dwa dalsze akapity: „Żydzi mnóstwo rzeczy oddali na przechowanie mieszczanom i chłopom. Przez cały dzień ludzie nosili jakieś toboły, kosze, maszyny do szycia itp. Za przechowanie w ciagu kilku dni dzieci i dorosłych dawano ogromne pieniądze, lecz chłopi z bliskich wsi boją się, bo za ukrywanie Żydów grozi kara śmierci, a donosicieli wszędzie jest pełno. Więcej wywożą dzieci do dalszych wsi, o czym wiem z pewnościa. Po południu Żydów prawie nie było widać. Wpłynęło to od razu na znaczne obniżenie cen na produkty wiejskie, bo zabrakło kupujących Żydów. Wśród ogółu mieszkańców napięcie też ogromne. Wiele osób chciałoby, żeby to już prędzej się skończyło - albo tak, albo tak, bo jednak ten paniczny nastrój Żydów udziela się wszystkim” ${ }^{28}$. Oprócz zachowań patologicznych Klukowski odnotował - w tym samym zapisku! - próby współdziałania, pomocy, handlu, a przede wszystkim wszechogarniający paniczny strach. Podobnie złożony obraz wyłania się z pozostałych zapisków Klukowskiego z lat 1942-1943. W istocie to opis katastrofy cywilizacyjnej spowodowanej przez Niemców, których przed dokończeniem dzieła zniszczenia powstrzymała jedynie klęska na froncie wschodnim na początku 1943 r. Skali tej katastrofy - dotykajacej i Żydów, i Polaków - nie moga oddać dwa wypreparowane cytaty, które, jak wynika z przypisu 53 (s. 325), Krzyżanowski najprawdopodobniej przeją ze Złotych żniw Grossa.

W książce Krzyżanowskiego brak podstawowej informacji, że na mocy rozporządzenia Hansa Franka z 15 X 1941 r. okupowane ziemie polskie stały się jedynym obszarem w Europie podbitej przez Niemcy, na którym za wszelka pomoc okazaną Żydom karano śmiercią ${ }^{29}$. Ani o tym, że Niemcy kierowali się przeważnie zasadą odpowiedzialności zbiorowej - najbardziej znanym przykładem jest rodzina Ulmów w Markowej pod Łańcutem. O postępującej, dramatycznej pauperyzacji, która sprawiała, że większość Polaków z trudnością sama utrzymywała się przy życiu, też z książki Krzyżanowskiego się nie dowiemy ${ }^{30}$. Również słowo „Żegota” nie pojawia się tu ani razu.

W ujęciu Krzyżanowskiego antysemityzm Polaków to pochodna ich nacjonalizmu i katolicyzmu. Trudno oczekiwać od Autora, by spróbował w ograniczonej

\footnotetext{
${ }^{27}$ Krytycznie o zachowaniu się „pewnej części ludności polskiej”, zwłaszcza „łazików”, Klukowski pisał też m.in. 9 V 1942. Zob. ibidem, s. 276-277.

${ }^{28}$ Ibidem, s. 272-273.

${ }^{29}$ Zob. np.: S. Chaskielewicz, Ukrywatem się w Warszawie. Styczeń 1943 - styczeń 1945, Kraków 1988, s. 187.

${ }^{30}$ Szerzej zob. R.C. Lucas, op. cit., s. 241.
} 
siłą rzeczy objętościowo i tematycznie książce zmierzyć się z jakże złożona historia polsko-żydowską w latach 1864-1939, a to w tym okresie trzeba by szukać odpowiedzi na pytania o postawy Żydów wobec Polaków i Polaków wobec Żydów. Niemniej dobrze byłoby o tej złożoności pamiętać.

Można by się spodziewać przynajmniej kontekstów wojennych. Jednak o doświadczeniu okupacji sowieckiej też tu nie przeczytamy. A przecież dostępne źródła nie pozostawiają wątpliwości, że to ona w znacznej mierze zaważyła na stosunku Polaków do Żydów, szczególnie w drugiej połowie 1941 r., gdy relacje z Kresów Wschodnich dotarły do Polski Centralnej oraz środowisk emigracyjnych. Wskazują na to m.in. raporty gen. Stefana Roweckiego wysyłane do Londynu pod koniec września $1941 \mathrm{r}$. Szacuje się, że we Lwowie, w Białymstoku czy Łucku trzy czwarte stanowisk kierowniczych w administracji objęli pod okupacją sowiecką Żydzi. Przed wojną na Uniwersytecie Lwowskim Polacy stanowili pośród studentów 70\%, Żydzi i Ukraińcy - po $15 \%$. Pod okupacja sowiecką odsetek studentów żydowskich wzrósł do $85 \%$, polskich spadł do $3 \%$, ukraińskich - do $12 \%{ }^{31}$. Podobne przykłady można mnożyć ${ }^{32}$. Na uwage zasługuje pogląd Ewy Kurek, że w tym czasie stosunki polsko-żydowskie - za sprawą wzajemnych urazów i stereotypów, które ostatnie wydarzenia zdawały się potwierdzać - stały się „najgorsze z możliwych” ${ }^{33}$.

Podobnie jak Klukowskiego, Łukasz Krzyżanowski spożytkował Jana Karskiego. W ślad za nim konstatuje, że antysemickie klisze stwarzały „coś w rodzaju wąskiej kładki, na której spotykały się zgodnie” szerokie warstwy polskiego społeczeństwa, niezależnie od różniących je poglądów w innych kwestiach (s. 140). Owa „waska kładka”, dodajmy, to cytat z raportu Karskiego przekazanego przezeń z okupowanej Polski do Francji. W przypisie 10 (s. 344) Krzyżanowski przyznaje, że cytat ten przepisał od Grossa, tym razem z jego Upiornej dekady, najwyraźniej nie zadając sobie trudu zapoznania się $\mathrm{z}$ całością dokumentu ${ }^{34}$. Czytelnik jego książki nie dowie się zatem, że przytoczony za Grossem cytat z raportu Karskiego pochodzi z lutego 1940 r., a więc z początku okupacji. Karski podkreślał, że „stosunek Żydów do Polaków i na odwrót pod okupacją niemiecką jest zagadnieniem bardzo ważnym i bardzo skomplikowanym". Ostrzegał, że Niemcy próbują w perfidny sposób przeciwstawić lud i elity, starając się wciagać polskie społeczeństwo w „rozwiazanie kwestii żydowskiej” i je zdemoralizować. Piszac o „waskiej kładce”, Karski zastrzegał w kolejnym zdaniu: „Oczywiście, że ta kładka jest równie wąska,

${ }^{31}$ Ibidem, s. 221-222.

${ }^{32} \mathrm{O}$ zmianach demograficznych na Kresach Wschodnich w latach 1939-1941 zob. K. Jasiewicz, Rzeczywistość sowiecka 1939-1941 w świadectwach polskich Żydów, Warszawa 2009, s. 39.

${ }^{33}$ E. Kurek, Stosunki polsko-żydowskie 1939-1945. Poza granica solidarności, wyd. 2, Warszawa 2016, s. 330.

${ }^{34} \mathrm{Na}$ zmanipulowanie przekazu Karskiego przez Grossa zwracała uwagę już w 1999 r. Agnieszka Magdziak-Miszewska podczas debaty zorganizowanej przez miesięcznik „Więź”. Zob. Polacy i Żydzi w upiornej dekadzie, „Więź” 1999, nr 7, s. 4-5. 
jak wielkie są chęci Niemców, aby ją podmurować i wzmocnić”35. Owszem, Karski wskazywał, że niektórzy spoglądają na Niemców „ciekawym i często zachwyconym wzrokiem”. Zwraca jednak uwagę jego dopisek, że „stosunek Polaków do Żydów w bardzo wielu wypadkach zmienił się pod wpływem tego, co się dzieje. Powszechnie podkreśla się w rozmowach przekraczające wszelkie granice bestialstwo Niemców w stosunku do tej części ludności, zamieszkującej ziemie polskie. W wielu wypadkach Polacy okazują w widoczny sposób współczucie Żydom. Jest to tym bardziej charakterystyczne, że takie widoczne okazywanie współczucia może się kończyć, lub często i kończy się, źle, dla tego, kto okazuje serce" ${ }^{36}$. Zaznaczmy też, że Karski wskazywał wpływ doświadczenia okupacji sowieckiej na postrzeganie Żydów przez Polaków: „w zasadzie jednak i w masie Żydzi stworzyli sytuację, w której Polacy uważają ich za oddanych bolszewikom i - śmiało można powiedzieć - czekają na moment, w którym będą mogli po prostu zemścić się na Żydach" ${ }^{37}$.

Nie chodzi tu o to, by usprawiedliwiać wstydliwe postawy Polaków wobec Żydów, lecz by uchwycić złożoność tamtego czasu, czego nawet nie próbuje robić zapatrzony w Grossa Krzyżanowski. Co gorsza, nonszalancko przywoływany przez nich raport Karskiego z lutego 1940 r. nie jest przecież jedynym jego przekazem na temat stosunków polsko-żydowskich. W styczniu 1943 r. ten sam Karski pisał: „To wszystko, co Niemcy robili w drugiej połowie 1942 r. z ludnościa żydowska, było tak straszliwe, [a] mimo wszystkie dotychczasowe bestialstwa Niemców społeczeństwo na tak potworne mordy było tak nieprzygotowane, że jedynym uczuciem górującym ponad wszystkie inne było oburzenie i zgroza. Jest to prawda i stwierdza to niewatpliwie sama ludność żydowska, iż często nieznane ręce rzucają poza budynek getta bochenki chleba, jarzyny itp.” I dalej: „Społeczeństwo ustosunkowuje się po ludzku - ustawia swój stosunek do Żydów jako do ludzi setkami tysięcy mordowanych. W tym ludzkim stosunku jest przede wszystkim współczucie z losem Żydów i oburzenie na to wszystko, co okupant z ludnością żydowska robi”. Karski wskazywał też na ewolucję postaw, „z nielicznymi wyjątkami”, tych sił politycznych, które dotychczas odnosiły się do Żydów krytycznie czy zgoła niechętnie: „wszystkie ośrodki narodowe, katolickie oraz katolicko-narodowe wyraziły we wstępnych artykułach swej prasy jak najżywsze oburzenie, potępienie i protest przeciwko temu wszystkiemu, co Niemcy z ludnościa żydowską robiły. Należy zacytować w pierwszym rzędzie wstępny artykuł w jednym z numerów «Walki» (oficjalnego organu Stronnictwa Narodowego) oraz specjalnie wydaną ulotkę, kolportowaną w dziesiątkach tysięcy egzemplarzy przez Front Odrodzenia Polski, organizację bojowego i ortodoksyjnego

\footnotetext{
${ }_{35}$ A. Eisenbach, Raport Jana Karskiego o sytuacji Żydów na okupowanych ziemiach polskich na poczatku 1940 r., „Dzieje Najnowsze” 1989, nr 2, s. 196.

${ }^{36}$ Ibidem, s. 197-198.

${ }^{37}$ Ibidem, s. 195.
} 
katolicyzmu. Atmosfera jest tego rodzaju w Generalnej Guberni, że zajęcie stanowiska w prasie czy w dyskusjach, czy na konferencjach organizacyjnych tego rodzaju, jak: «dobrze tak Żydom, nareszcie rozwiązana będzie kwestia żydowska, ja jestem antysemitą» - byłoby przyjęte jako objaw zupełnego zdziczenia, jako opinia niesmaczna, a nie jako przedmiot dyskusji”. Karski przypominał też, że Niemcy „zawsze karzą tych wszystkich”, którzy okazali Żydom jakąkolwiek pomoc, a niesienia pomocy nie ułatwia i to, że „wygląd zewnętrzny Żydów istotnie uniemożliwia im wymknięcie się śmierci”38.

Co więcej, wyrażano obawy, że po Żydach totalnej eksterminacji poddani zostaną Polacy. Nawet gubernator dystryktu warszawskiego Ludwig Fischer pisał wówczas w raporcie, że „wielu Polaków przypuszcza, że po wysiedleniu Żydów przyjdzie kolej na ludność polska"39. Podobne nastroje rejestrował wspominany wcześniej Klukowski: „A nam się zdaje, że społeczeństwo polskie w kraju goni resztkami sił, że skazani jesteśmy na planową zagładę i że tylko rychły koniec wojny może nas jeszcze uratować. Zwłaszcza gdy patrzymy na to, co się dzieje u nas, jak wysiedlają całe wsie, a potem pełnymi pociagami wywożą gdzieś w nieznane, osobno mężczyzn, osobno kobiety i dzieci, jak systematycznie tępią całą naszą inteligencję i elitę umysłową"

Osobny problem, też pominięty przez Krzyżanowskiego, to mechanizmy propagandy niemieckiej, która po ujawnieniu zbrodni katyńskiej nasiliła kampanię wymierzoną przeciwko bolszewickiej „żydokomunie”, by złamać opór PPP, wbić klin między aliantów i rozegrać Polaków dla własnych celów ${ }^{41}$. To jednak właśnie PPP alarmowało na różne sposoby Zachód o dokonywanej przez Niemców zagładzie Żydów, o czym obszernie pisał przez kilka dekad m.in. Bartoszewski ${ }^{42}$.

Zastanawia w książce Krzyżanowskiego opis pierwszych tygodni po zajęciu (wyzwoleniu) Radomia przez Armię Czerwona. Autor przytacza wzruszajace relacje Żydów, którzy powracali do Radomia. Można zrozumieć, co czuli ci, którzy widzieli przedwojenny cmentarz żydowski zamieniony w pastwisko. (Krzyżanowski nie podaje jednak, kto dopuścił się dewastacji cmentarza; wydaje się, że doszło do niej jeszcze podczas okupacji). Zapada w pamięć zwłaszcza jedna z relacji - Tuwii Frydmana. Gdy wraz ze swoim towarzyszem pojawił się na ulicy Radomia, patrzono na nich jak na „zjawę lub

${ }^{38}$ Cyt. za: Polacy i Żydzi pod okupacja niemiecka 1939-1945. Studia i materiaty, red. A. Żbikowski, Warszawa 2006, s. 156-157.

${ }^{39}$ Raport Gubernatora Dystryktu Warszawskiego $z$ dn. 15 VIII za miesiace czerwiec $i$ lipiec 1942 r., w: Raporty Ludwiga Fischera gubernatora Dystryktu Warszawskiego 1939-1944, wybór i oprac. K. Dunin-Wasowicz i in., Warszawa 1987, s. 543.

${ }^{40}$ Z. Klukowski, op. cit., s. 317, zapisek z 14 XII 1942.

${ }^{41}$ Zob. np.: J. Goebbels, Dzienniki, t. III: 1943-1945, oprac. E.C. Król, Warszawa 2014, s. 67-68, zapisek z 5 V 1943.

${ }^{42}$ W. Bartoszewski, op. cit., s. 22. Zob. też: D.S. Wyman, Pozostawieni swojemu losowi. Ameryka wobec Holocaustu 1941-1945, tłum. W. Sadkowski, Warszawa 1994, s. 51. 
dzikie zwierzęta, które pouciekały z klatki cyrkowej” (s. 92). Mimo że było ich niewielu, miało ich spotkać niechętne powitanie.

Jednak liczba przebywających w Radomiu Żydów szybko rosła. Jak podaje Krzyżanowski, w marcu 1945 r. było ich już prawie 600, a w sierpniu - 959 (s. 95). Rok później liczba Żydów w Radomiu miała spaść do 111, zdecydowana większość bowiem wyemigrowała z Polski. Niemniej do 1949 r. powstały na terenie Radomia Komitet Żydowski odnotował w rejestrach „co najmniej 1740 osób”, które na krócej czy dłużej pojawiły się w mieście (s. 95). Liczby te budzą watpliwości, których Krzyżanowski nie wyjaśnia. Nie dowiadujemy się, ilu spośród 959 Żydów, którzy w sierpniu 1945 r. osiedli w Radomiu, mieszkało tu również przed wojną. Czy byli to obywatele Radomia, czy przybysze z zewnątrz? Nie dowiemy się też z książki Krzyżanowskiego, ilu polskich mieszkańców Radomia przeżyło wojnę. Brak odpowiedzi na te pytania nie ułatwia zrozumienia powojennych relacji polsko-żydowskich.

Nasuwaja się kolejne pytania. Czy na pewno polski antysemityzm był głównym powodem emigracji Żydów z Polski? Czy nie ważniejszy czynnik stanowiło tworzenie państwa żydowskiego w Palestynie, tym bardziej że organizacje syjonistyczne dokładały wszelkich starań, by do Palestyny dotarło jak najwięcej Żydów, zwiększało to bowiem szansę powodzenia tego przedsięwzięcia? Z jakich obszarów Rzeczypospolitej pochodzili Żydzi, którzy emigrowali? Czy w znacznej mierze nie z Kresów Wschodnich, które znalazły się w 1945 r. w granicach Związku Sowieckiego? W książce Krzyżanowskiego rola syjonizmu wzmiankowana jest tylko marginalnie.

W ślad za Grossem Krzyżanowski przedstawia powojenne relacje polsko-żydowskie z punktu widzenia antyżydowskiej przemocy ze strony Polaków. Sugeruje, że do „eskalacji przemocy” doszło latem 1945 r. (s. 95). Konkluduje, że Żydzi radomscy (i Żydzi w ogóle) funkcjonowali w „morzu nienawiści” (s. 181). Dlatego też druga część książki zatytułowana jest Przemoc. Głównym dowodem na potwierdzenie tezy o antyżydowskiej przemocy ma być zamordowanie łącznie dziewięciu Żydów w 1945 r. Trzeba uznać za dużą zasługę Krzyżanowskiego, że okoliczności tych zbrodni zrekonstruował możliwie starannie. Co ciekawe, sam doszedł do wniosku, że przynajmniej pięciu z dziewięciu morderstw raczej nie można łączyć z antysemityzmem (w każdym razie nie jako głównym motywem zbrodni), lecz z rabunkiem. To ważna informacja, która wpisuje się w obraz powojennego chaosu, który dotykał wszystkich mieszkańców Polski; wskutek wojny życie ludzkie niewiele znaczyło. Okrucieństwem wyróżnia się mord czworga Żydów w nocy 10 na 11 VIII 1945 r., który wkrótce uznany został za pogrom, choć sam Krzyżanowski bierze tym razem to słowo w cudzysłów. Sprawców nie wykryto. Jednym z zamordowanych okazał się porucznik Armii Czerwonej. Mimo tych niejasności Krzyżanowski - poprzez analogię do pogromów w Kielcach, Rzeszowie i Krakowie - stawia jednak tezę, że „nie można wskazać innego niż nienawiść do Żydów motywu, którym kierowali się sprawcy tego zabójstwa" (s. 136). Dosadność tej tezy nie 
idzie jednak $\mathrm{w}$ parze z moca przedstawionych wcześniej argumentów. Czy w ogóle nie wchodził w grę motyw polityczny? Inna rzecz, że należałoby też zadać pytanie o sensowność określania mianem „masowego” (s. 136) pogromu w Krakowie (11 VIII 1945 r.), skoro zginęła wtedy jedna osoba, a zwłaszcza pogromu w Rzeszowie (11-12 VI 1945 r.), w którego trakcie ostatecznie nikt nie zginął (książka Krzysztofa Kaczmarskiego na ten temat nie została uwzględniona przez Krzyżanowskiego ${ }^{43}$ ).

Skupiając uwage przede wszystkim na przemocy antyżydowskiej, Krzyżanowski sugeruje, że łączyły się w niej, mimo różnic, nowa administracja miasta, Milicja Obywatelska, Urząd Bezpieczeństwa, podziemie antykomunistyczne, Kościół katolicki. Oznaczałoby to, że podział na obóz komunistyczny i niepodległościowy stał się drugorzędny, nadrzędnym bowiem celem jednych i drugich było wyrugowanie z Polski Żydów. Również i ten model opisu Krzyżanowski przejął od Grossa. Czy pasuje do Radomia? Dowodem na antysemityzm administracji miasta ma być raport referenta ds. mniejszości żydowskiej w Ministerstwie Administracji Publicznej, Mojżesza Rubinsteina, który w lutym 1945 r. ocenił, że wprawdzie władze Radomia dobrze się odnosza do Żydów, ale „niektóre ogniwa aparatu administracyjnego (niższego) stosuja metody antysemickie" (s. 152). Z kolei starosta Radomia odmówił przyjęcia delegacji Żydów (s. 154). Z braku dalszych przykładów Krzyżanowski posiłkuje się danymi z innych miast, np. Ostrowca. Ostatecznie pozostaje niejasne, czy postawę powojennych władz Radomia (z dominującą rolą PPR) można uznać za antysemicką.

Jeszcze większe wątpliwości wzbudza teza, że „antysemityzm był powszechny zarówno wśród pracowników służb mających stać na straży prawa tuż po wojnie w Polsce, Milicji Obywatelskiej i Urzędu Bezpieczeństwa" (s. 140). Krzyżanowski opiera ja, co nie zaskakuje, na obserwacjach Jana Tomasza Grossa oraz Marcina Zaremby. Jednak w Wielkiej trwodze, do której odsyła przypisem 1 (s. 140, 344), obraz okazuje się nieco bardziej złożony. Owszem, Zaremba przytaczał przykłady incydentów z udziałem milicjantów, które mogły stanowić dowód na ich antysemickie nastawienie, choć można by dyskutować, czy świadczą one aż o „powszechności przekonań antysemickich w tej grupie zawodowej”. Zarazem Zaremba zwracał uwage, że ich podłożem był także „konflikt między MO i UB” i przekonanie funkcjonariuszy MO o dominującej roli Żydów w aparacie bezpieczeństwa ${ }^{44}$. Wedle Krzyżanowskiego „szczególny wgląd w antyżydowskie nastroje panujące w radomskiej milicji" umożliwiaja akta procesu Jana Waca, funkcjonariusza MO oskarżonego w 1949 r. o przyjmowanie łapówek. Wac zeznał, że

${ }^{43}$ K. Kaczmarski, Pogrom, którego nie byto. Rzeszów, 11-12 czerwca 1945 r. Fakty, hipotezy, dokumenty, Rzeszów 2008, s. 19-36.

${ }^{44}$ M. Zaremba, Wielka trwoga. Polska 1944-1947. Ludowa reakcja na kryzys, Kraków-Warszawa 2012, s. 269. 
oskarżono go o łapówkarstwo, dlatego że jest Żydem. Krzyżanowski referuje sprawę z punktu widzenia Waca i dochodzi do wniosku, że antysemityzm jego głównego oskarżyciela nie ulega watpliwości. W procesie zapadł wyrok skazujący, ale Najwyższy Sąd Wojskowy sprawę umorzył. Sprawa może zatem budzić wątpliwości (s. 145-149).

Antysemicką instytucją okazuje się także Urząd Bezpieczeństwa, na co ma wskazywać antysemityzm partyzantów Armii Ludowej, którzy zasilili po wojnie szeregi „bezpieki”; jako koronny przykład Krzyżanowski podaje w ślad za Tokarską-Bakir oddział AL „Świt” na Kielecczyźnie. Na czym konkretnie polegał antysemityzm UB akurat w Radomiu, z książki Krzyżanowskiego się nie dowiadujemy (s. 149-150).

Antysemityzm miał też stanowić główny wyróżnik „podziemia antykomunistycznego". Dowodem na to - pojawienie się ulotek wzywających Żydów do opuszczenia Radomia w związku z ich działalnościa na rzecz narzuconego reżimu. Autorstwo Krzyżanowski przypisuje Stefanowi Bembińskiemu, dowódcy Oddziału Wolności Sokół, który miał też prowadzić akcję buntowania szeregowych żołnierzy „armii Żymierskiego” przeciwko oficerom jako Rosjanom albo Żydom (s. 139). Klisze antysemickie ponoć były cechą całego „podziemia antykomunistycznego", a na poparcie tej tezy Krzyżanowski przywołuje „badania prowadzone przez Joannę Tokarska-Bakir oraz przez Jana Tomasza Grossa" (s. 140). Na tym opis podziemia się kończy. W Atlasie polskiego podziemia niepodległościowego Krzyżanowski znalazłby jednak informacje, które skomplikowałyby ten obraz ${ }^{45}$. O tym, że żołnierze podziemia starali się przede wszystkim ratować niepodległość Polski, również tu nie przeczytamy.

Ten antysemicki układ dopełnia w ujęciu Krzyżanowskiego Kościół katolicki. Pomińmy już to, że opis Kościoła Autor pomieścił w podrozdziale zatytułowanym „Administracja lokalna i przedstawiciele Kościoła katolickiego wobec Żydów”, co zdaje się sugerować wspólnotę duchowieństwa i aparatu nowej władzy. O antysemityzmie Kościoła ma świadczyć jego postawa wobec pogromu kieleckiego. Jak pisze Krzyżanowski, „wśród opinii wypowiadanych przez hierarchów kościelnych po pogromie kieleckim wskazać można również głosy sugerujące, że w powojennej Polsce nie ma miejsca dla Żydów. Takie stanowisko miał zaprezentować biskup lubelski Stefan Wyszyński podczas spotkania z delegatami żydowskiej społeczności Lublina” (s. 156). Problem polega na tym, że źródłem tej wypowiedzi jest „odpis pisma Wojewódzkiego Urzędu Informacji i Propagandy” z 23 VII 1946 r., a zatem nawet nie oryginał. Jak przyznaje sam Krzyżanowski w przypisie 19, „do tej pory nie udało się odnaleźć żadnych źródeł kościelnych dokumentujących przebieg tego spotkania" (s. 347). Nie przeszkodziło mu to jednak umieścić rzekomej wypowiedzi bpa Stefana Wyszyńskiego w głównym tekście książki (do przypisu raczej

${ }^{45}$ Zob. np.: Atlas polskiego podziemia niepodległościowego 1944-1956, red. R. Wnuk i in., Warszawa-Lublin 2007, s. 268. 
mało kto zajrzy). O tym, że w tym właśnie czasie bp Wyszyński w listach pasterskich kierowanych do wiernych Lubelszczyzny wzywał do „odbudowy moralności i godności człowieka, bo wojna w tym zakresie poczyniła ogromne spustoszenia, i to we wszystkich grupach społecznych", Krzyżanowski już nie wspomina ${ }^{46}$. O antysemityzmie Kościoła w Radomiu Krzyżanowski tak pisze: „W wypowiedziach niektórych księży można wręcz napotkać słowa zachęty do rozprawy z Żydami. W jednej z głównych świątyń Radomia, kościele Mariackim, ksiądz miał powiedzieć: "weźcie miotły, by czym prędzej wyczyścić tę hołotę, bo im wcześniej, tym lepiej, Żydzi sa wrogami naszymi»” (s. 157). „Miał powiedzieć" - jak czytamy w przypisie 20 - wedle „sprawozdania instruktorów KC PPR z pobytu w województwie kieleckim w czasie od 4 do 15 lipca 1946 r." (s. 347). Trudno przypuszczać, by Krzyżanowski nie zdawał sobie sprawy, że intencja propagandy komunistycznej było nakreślenie jak najbardziej negatywnego wizerunku Kościoła katolickiego - również z myśla o zagranicznej opinii publicznej - a zatem tego rodzaju rzekome cytaty należy przytaczać z największą ostrożnością ${ }^{47}$. Na tym też refleksja Krzyżanowskiego nad Kościołem katolickim się kończy. Wszystkie publikacje naukowe, które kolidowałyby z jego teza, zostały zignorowane ${ }^{48}$.

W układance zestawionej przez Krzyżanowskiego zabrakło innego elementu - NKWD. O tym, że NKWD na pewien czas przejęło gmach zajmowany przez radomskie Gestapo, Krzyżanowski nie pisze wprost. Podobnie jak i o tym, że po NKWD gmach ów zajął Powiatowy Urząd Bezpieczeństwa Publicznego, który skupił się na rozpracowaniu podziemia niepodległościowego. Jak wpływało to na nastroje mieszkańców Radomia?

Podobnie jak w części I, również i tu brakuje kontekstów. Można pochwalić Autora za to, że stara się zdekonstruować problem ,żydokomuny”. Nasuwa się jednak pytanie, czy właściwą metodą jest rozpisywanie się o antysemityzmie Urzędu Bezpieczeństwa i jednoczesne wymazywanie z historii Jakuba Bermana? Brak jakiejkolwiek wzmianki o tym, że komuniści pochodzenia żydowskiego odegrali ważną rolę w narzuceniu powojennej Polsce komunizmu, stanowi ucieczkę od problemu, a nie jego wyjaśnienie ${ }^{49}$. Ułatwia to

${ }^{46}$ E.K. Czaczkowska, Kardynat Wyszyński. Biografia, Kraków 2013, s. 74.

${ }^{47}$ W książce Komunizm po polsku Nikołaj Iwanow zauważa: „Sowieccy przedstawiciele w Polsce uważnie śledzili wszystkie przejawy stosunków polsko-żydowskich. Każdy konflikt na tle narodowościowym mógł się przydać w procesie sowietyzacji, a zwłaszcza element tak zapalny, jak kwestia żydowska. Szczególnie ważne było to, że opinia publiczna w Stanach Zjednoczonych okazywała się wyjątkowo wyczulona na problem prześladowania Żydów. Dlatego przy każdej nadarzającej się okazji środki masowego przekazu, zarówno sowieckie, jak i komunistyczne polskie, oskarżały przeciwników Polski Ludowej o antysemityzm”. N. Iwanow, Komunizm po polsku. Historia komunizacji Polski widziana z Kremla, Kraków 2017, s. 324.

${ }^{48}$ J. Żaryn, Hierarchia Kościoła katolickiego wobec relacji polsko-żydowskich w latach 19451947, w: Wokót pogromu kieleckiego, red. Ł. Kamiński, J. Żaryn, Warszawa 2006, s. 75-110.

${ }^{49} \mathrm{Na}$ ten temat zob. A. Paczkowski, Żydzi w UB. Próba weryfikacji stereotypu, w: Komunizm. Ideologia, system, ludzie, red. T. Szarota, Warszawa 2001, s. 192-204; K. Szwagrzyk, Żydzi 
przedstawienie Polaków jako irracjonalnych antysemitów, ale czy na pewno o to chodzi w pracy naukowej? Metodę opisywania skomplikowanych relacji w trójkącie Żydzi - komuniści - Polacy zaproponował Marek J. Chodakiewicz w książce Po Zagtadzie, do której Krzyżanowski mógłby się odnieść, choćby i krytycznie ${ }^{50}$. Zaangażowanie części Żydów po stronie nowego reżimu można zracjonalizować, niemniej należy też zadać pytanie o odbiór społeczny ich postaw. Również o recepcję proreżimowych deklaracji Centralnego Komitetu Żydów w Polsce, w tym wystapień przeciwko „zbrodniarzom spod znaku AK i NSZ”, wysługującym się „bandytom hitlerowskim” i pozostającym „w ścisłym kontakcie «z rządem» londyńskim” (odezwa z 4 II 1945) ${ }^{51}$. Jak odbierali tego rodzaju enuncjacje żołnierze podziemia niepodległościowego?

Warto tu odnotować obserwację rosyjskiego historyka Nikołaja Iwanowa, że „żadna partia żydowska w Polsce z syjonistami włącznie nie wypowiadała się przeciwko sowietyzacji Polski, żadna nie wzywała swych zwolenników do głosowania na «nie» w referendum 1946 roku lub przeciwko koalicji PPR-PPS i ich sojuszników w wyborach do Sejmu Ustawodawczego 19 stycznia 1947 roku". Z przytaczanych przez Iwanowa danych wynika, że spośród zaangażowanych politycznie Żydów zdecydowana większość działała w PPR (,liczba Żydów członków PPR była większa od liczby Żydów należących do wszystkich innych partii politycznych razem wziętych i sięgała siedmiu tysięcy”). Jak wyjaśnia Iwanow, postawę Żydów można tłumaczyć „tradycyjna żydowska polityką lojalności wobec każdej władzy państwowej, a częściowo również tym, że w komunistach Żydzi widzieli swego naturalnego sojusznika w obliczu polskiego antysemityzmu". Miało to jednak i ten skutek, że w oczach wielu Polaków Żydzi tym bardziej stawali się „nowymi rządcami Polski”².

Aby uniknać komplikacji, Krzyżanowski pomija istotne źródła. Przykładem zbiór raportów NKWD z Polski z lat 1944-1946, wydanych w tomie pt. Teczka specjalna J.W. Stalina. Jeden z zawartych tu dokumentów Krzyżanowski przytacza, ale, o dziwo, nie ten, w którym mowa o Radomiu. Chodzi o raport Nikołaja Sieliwanowskiego przesłany Berii 20 X 1945 r. Z jednej strony Sieliwanowski przedstawił dane dotyczące wystapień antysemickich Polaków, z drugiej - roli Żydów w aparacie nowej władzy, wyliczając odsetki Żydów zajmujących stanowiska kierownicze. Mamy tu też wzmianke o Centralnym Biurze Kontroli Prasy, w którym ponoć pracowało „do 50\% Żydów”. W jego oddziale w Radomiu Żydzi mieli stanowić 82,3\% zatrudnionych pracowników. Sieliwanowski ostrzegał, że „sytuacja ta wywołuje gwałtowne niezadowolenie Polaków, którzy mówią o panoszeniu się [Żydów] w ministerstwach i innych

w kierownictwie UB. Stereotyp czy rzeczywistość?, „Biuletyn Instytutu Pamięci Narodowej” 2005, nr 11, s. 37-42.

${ }^{50}$ M.J. Chodakiewicz, Po Zagładzie. Stosunki polsko-żydowskie 1944-1947, Warszawa 2008, s. 40 .

${ }^{51}$ Cyt. za: J. Żaryn, op. cit., s. 110.

${ }^{52}$ N. Iwanow, op. cit., s. 321-323. 
polskich urzędach" ${ }^{53}$. Powraca tu pytanie o wspomnianych przez Krzyżanowskiego 959 Żydach, którzy osiedli w Radomiu do lata 1945 r. Czy byli to dawni sąsiedzi radomskich Polaków, czy może nieznani tu dotąd funkcjonariusze reżimu komunistycznego? Jeśli to drugie, zagadnienie przemocy antyżydowskiej nabierałoby innego znaczenia.

Wybitny pisarz pochodzenia żydowskiego Marian Brandys, wspominając antysemickie zachowania i dowcipy Polaków tuż po wojnie, po latach nabrawszy już dystansu do ówczesnych wydarzeń - pisał w swoim dzienniku, co warto przypomnieć w całości: „Dziś lepiej rozumiem społeczno-polityczne uwarunkowanie. To, co się zaczęło dziać w pierwszych latach po wojnie, było nie do strawienia dla przeciętnego Polaka, wychowanego w tradycjach narodowo-katolickich lat przedwojennych. Przypominało to koszmarny sen patrioty-narodowca, którego od kołyski straszono złym brodatym Żydem, czyhającym na niegrzeczne dzieci, a później - przerażająca wizją «judeo-Polonii». W Polsce, gdzie przed wojną żydowska mniejszość miała praktycznie zamkniętą drogę do korpusu oficerskiego, do policji, do sądownictwa - zaroiło się naraz od Żydów wyższych oficerów, Żydów wyższych funkcjonariuszy służby bezpieczeństwa, Żydów sędziów i prokuratorów. Poza tym Żydzi zajęli znaczną część wyższych stanowisk w Ministerstwie Spraw Zagranicznych i w Ministerstwie Propagandy, wydawnictwach i w redakcjach, a także - i to chyba najważniejsze - w centralnych i wojewódzkich władzach partyjnych; wytworzył się przedziwny stan rzeczy. Okupacja hitlerowska wyniszczyła całkowicie masy ubogiego ortodoksyjnego żydostwa wsi, miasteczek i miast, natomiast ci Żydzi, którzy pozostali, weszli niemal w całości do nowej klasy rządzącej i skupili się w kilku największych miastach. Wskutek tego przeciętnemu Polakowi, załatwiającemu sprawy w biurach i w urzędach, majacemu do czynienia z sądami, z wojskiem, z policja, mogło się wydawać, że - pomimo sześcioletniej eksterminacji hitlerowskiej - Żydów jest w Polsce nie mniej, lecz więcej, niż było ich przed wojna. Przy czym nie byli to Żydzi zasymilowani, wrośnięci w kulturę polska, upodobnieni do rdzennie polskiego otoczenia, lecz w większości Żydzi jak najbardziej odmienni od autochtonów, wywodzacy się wprost z getta małych miasteczek ukraińskich, białoruskich i litewskich. Obcy polskiej kulturze, często wychowani w nienawiści do «burżuazyjno-szlacheckiej» Polski, aroganccy i o niewyżytych kompleksach, nie zawsze dobrze mówiący po polsku. Stopniowo w oczach wielu przeciętnych Polaków Żydzi zaczęli utożsamiać się z nową władzą, z komunizmem, z demokracja, z hegemonią Związku Radzieckiego. Nagłe wywyższenie Żydów powodowało tym większy szok, że w ciągu sześciu lat wojny przeciętny Polak był świadkiem ich najgłębszego pognębienia i wyobcowania. W wielu sercach polskich współczucie ustępowało miejsca mściwej niechęci. Pamiętam,

${ }^{53}$ Teczka specjalna J.W. Stalina. Raporty NKWD z Polski 1944-1946, oprac. T. Cariewskaja i in., Warszawa 1998, s. 421-422. 
jakim przerażeniem napełniły mnie słowa pewnego prostego człowieka: «Gdyby jeszcze raz się to powtórzyło - powiedział - już bym Żydów nie ratował». A ten człowiek w czasie okupacji rzeczywiście ratował Żydów, często z narażeniem życia..." ${ }^{54}$ Czy nie warto by pokusić się o rozwiązanie tego węzła gordyjskiego?

Dochodzi do tego kolejny czynnik, na który blisko trzy dekady temu wskazał Stanisław Ciesielski. Wedle tego historyka to właśnie w rejonie radomsko-kieleckim szczególnie wyraźnie ujawniły się w 1945 r. „nastroje antyrządowe", zwłaszcza w dawnych zakładach przemysłu zbrojeniowego oraz wśród kolejarzy. Z cytowanych przez Ciesielskiego raportów wynika, że robotnicy narzekali, iż „doczekali się takich czasów, że muszą przemawiać przed wrona, wskazując przy tym na orła bez korony, że zamiast chleba dali im pięcioramienna gwiazdę", protestowali także przeciwko zaborowi Kresów Wschodnich ${ }^{55}$. Wydaje się, że atmosfera była tu tak napięta, iż byle iskra mogła doprowadzić do eksplozji. Odpowiedzialność za ten stan rzeczy ponosił narzucony Polsce reżim komunistyczny. Tego rodzaju kontekstów również próżno szukać w pracy Krzyżanowskiego.

Najciekawsza wydaje się trzecia część książki, pt. „Społeczność”. Krzyżanowskiemu udało się pokazać - głównie dzięki zebranym relacjom - odtwarzanie społeczności żydowskiej oraz jej instytucji, działalność OKŻ, sytuacje zawodową i materialną ludności żydowskiej, upamiętnianie pomordowanych (pomnik odsłonięto dopiero w 1950 r.). Szczególnie interesująco wypada problem zerwania ciagłości elit. Na przykładzie Nauma Szenderowicza Krzyżanowski znakomicie opisał postrzeganie byłych członków Judenratu przez społeczność żydowska. Równie ciekawie wypada odtworzenie mechanizmu wyłaniania się nowych liderów.

I tu jednak powracają wątpliwości. Pod koniec części II Krzyżanowski stawia tezę, że „żyjąc w otoczeniu, które (często całkiem słusznie) jawiło im się jako «morze nienawiści», Żydzi byli w zasadzie niewidoczni w społecznym pejzażu powojennego miasta" (s. 181). W części III dowiadujemy się jednak, że już wiosną 1945 r. Żydzi w Radomiu uruchomili „trzy zakłady krawieckie, trzy zegarmistrzowskie, a także zakład kamaszniczy, jubilerski, szewski, fryzjerski, czapniczy i tapicerski oraz laboratorium techniczno-dentystyczne i wędliniarnia", co potwierdza cytowany przez Krzyżanowskiego raport OKŻ (s. 194). Świadczyłoby to raczej o czymś odwrotnym - wyrazistej obecności w przestrzeni miasta. Gdyby Żydów rzeczywiście otaczało „morze nienawiści”, tak wiele różnych warsztatów chybaby nie zaistniało.

${ }_{54}$ M. Brandys, Dziennik 1976-1977, Warszawa 1996, s. 235-236, zapisek z 13 maja 1977. Podobne głosy: Z. Hertz, Listy do Czestawa Miłosza 1952-1979, Paryż 1992, s. 268, list z 17 IV 1968; K. Brandys, Miesiace, „Kultura” (paryska) 1983, nr 6, s. 33-34.

${ }^{55}$ S. Ciesielski, Nastroje polityczne wśród robotników w Polsce w latach 1945-1946 (w świetle dokumentów Polskiej Partii Robotniczej), „Dzieje Najnowsze” 1989, nr 1, s. 112. 
Nie ma też pewności, czy materialne warunki życia Polaków po wojnie były rzeczywiście lepsze niż Żydów. Zapewne wiele zależało od czasu i miejsca. Z badań historyków, z których nie skorzystał Krzyżanowski, wyłania się bardziej skomplikowany obraz. Wspominany już Stanisław Ciesielski, opierając się na sprawozdaniach inspektorów KC PPR, pisał: „W sierpniu 1945 roku w Łodzi na przeszło 20 tysięcy zamieszkujących wówczas Żydów, według informacji [Komitetu Łódzkiego] PPR, ani jeden nie był zatrudniony bezpośrednio przy warsztacie produkcyjnym w fabryce. Jeżeli niektórzy pracowali w przemyśle, to na stanowiskach kierowniczych albo w administracji zakładowej. Spośród tej liczby 9 tysięcy, szczególnie młodzieży żydowskiej, było zarejestrowanych jako bezrobotni. W tym samym czasie władze szkolne wysyłały dzieci do akcji żniwnej, co wywoływało akcje typu - a dlaczego zamiast dzieci nie zatrudniono bezrobotnych Żydów? [...] Wskazywano, iż krążą opinie, że większość Żydów pełniących funkcje państwowe nie miała nic wspólnego w przeszłości z ruchem robotniczym czy demokratyczną ideologia, że w większości wywodzą się ze środowisk burżuazyjnych i drobnomieszczańskich, że na stanowiska dostaja się dzięki protekcji współziomków, by potem samemu obdzielać koncesjami handlowymi, atrakcyjnymi towarami itp. swa dalszą rodzinę" ${ }^{56}$. Trudno się nie zgodzić z Ciesielskim, że opinie te wymagałyby starannej weryfikacji. Wyłania się z tych opisów obraz wzajemnego niezrozumienia. Nowsze badania przynosza podobne obserwacje. Łukasz Kamiński, analizując nastroje w środowiskach robotniczych, konstatuje: „Niechęć do Żydów nie wypływała przeważnie z uprzedzeń rasowych czy religijnych. Stali się w oczach polskiego społeczeństwa symbolami obcej, narzuconej władzy. Żydzi ucieleśniali jej przedstawicieli - oficera UB czy PPR-owca. Niechęć tę pogłębiał wyższy status ekonomiczny Żydów, otrzymujących wsparcie od licznych organizacji diaspory" ${ }^{57}$. Kwestia pomocy dla Żydów, płynącej po wojnie z diaspory, tylko marginalnie pojawia się w książce Krzyżanowskiego.

Najwięcej wątpliwości budzi ostatnia część omawianej pracy, pt. „Mienie”, napisana wyraźnie pod wpływem zarówno Grossa, jak i Ledera. Otwiera ja następująca konstatacja Autora: „Losy mienia żydowskiego w Polsce tuż po II wojnie światowej właściwie nie maja swojej fotograficznej dokumentacji. Przewłaszczenie, które nastapiło w czasie okupacji niemieckiej i w pierwszych latach powojennych, było wszechobecne, ale rzadko działo się przed obiektywem aparatu. Tym większą wartość ma siedem fotografii wykonanych w Radomiu w sierpniu lub wrześniu 1942 roku, już po wywiezieniu mieszkańców dużego getta do obozu zagłady w Treblince. Znajdują się na końcu albumu dokumentującego przebieg Zagłady w Radomiu i Szydłowcu. W latach sześćdziesiątych album trafił do archiwum Instytutu Yad Vashem w Jerozolimie. Niewiele wiadomo o autorze zdjęć. Być może nazywał się

${ }^{56}$ Ibidem, s. 114.

${ }^{57}$ Ł. Kamiński, Strajki robotnicze w Polsce w latach 1945-1948, Wrocław 1999, s. 47. 
Heinrich Moepken i w czasie II wojny światowej był niemieckim policjantem stacjonującym w Radomiu lub okolicy" (s. 251).

$\mathrm{Z}$ pewnością ów album to cenne znalezisko, choć przypis 1 wskazuje, że mamy tu do czynienia $\mathrm{z}$ albumem przygotowanym po wojnie przez historyków żydowskich, a nie albumem niemieckim z czasu wojny (s. 364). Co widzimy na fotografiach? Wedle Krzyżanowskiego: „Na głównej ulicy getta stłoczone chłopskie furmanki wypakowane do granic możliwości żydowskim dobytkiem. W jednej chwili mienie żydowskie stało się «pożydowskim». Wszystkie drzwi i okna domów sa pootwierane, zupełnie jakby w zapraszającym wezwaniu: «Bierzcie!» Pod ścianami kamienic wystawiony dobytek. Szafy, kredensy, balie, krzesła, stołki, pęknięte lustro, krawiecki manekin. Być może część z tych rzeczy trafi później do niemieckich magazynów, ale czy wszystkie? W plątaninie mebli, wozów i ludzi prawie nieobecni są Niemcy. Na jednym zdjęciu widać stół, zza którego nadzorują furmanki wywożące dobytek. $\mathrm{Na}$ innym obecny jest granatowy policjant. Czuć pośpieszna, gorączkowa atmosferę, ale nie grozę" (s. 251). Być może Krzyżanowski ma rację. Niemniej uważne przyjrzenie się opublikowanym przezeń zdjęciom skłania tė̇ do innych refleksji. Przede wszystkim uderza to, że nie widać tu uśmiechniętych twarzy. Na żadnym ze zdjęć nie ma objawów radości czy euforii. Znaczną część uchwyconych przez fotografa postaci stanowią kobiety. Nie sposób zgodzić się z Krzyżanowskim, że „prawie nieobecni sa Niemcy”. Nie trzeba być znawca niemieckiego umundurowania (wystarczy skopiować zdjęcia i je dostatecznie powiększyć), by stwierdzić, że Niemcy widoczni sa - i to w wyraźnych rolach organizatorów - na trzech spośród siedmiu zdjęć (na pierwszym widać m.in. żołnierza niemieckiego w pełnym rynsztunku - z hełmem na głowie i karabinem na ramieniu). To zaś każe zapytać o cel transportu mebli i garnków (te rzeczy przeważają na zdjęciach). Może jednak właśnie niemieckie magazyny? Mimo że sam Krzyżanowski nie wydaje się w pełni przekonany, pospiesznie przechodzi do pytań retorycznych, które sprawiają wrażenie szantażu emocjonalnego wobec czytelnika: „Ile polskich dzieci będzie usypianych w kołysce stojącej teraz wśród dobytku przygotowanego do wywiezienia? Czy jedzenie przyrządzone w emaliowanych garnkach, które bezpańskie stoją na bruku, będzie smakowało nowym właścicielom? Czy ktoś w ogóle będzie pamiętał, skąd wzięły się w ich domach te przedmioty?" (s. 252).

Fałszerstwo dokonane przez Grossa w Złotych żniwach - publikacja zdjęcia przedstawiającego rzekomo polskich chłopów rozgrzebujacych pola po obozie zagłady w Treblince $\mathrm{w}$ poszukiwaniu żydowskiego złota (w rzeczywistości przedstawia ono zupełnie inną sytuację) - powinno skutkować ostrożnościa i nieufnością do fotografii dokumentujących jakoby polski antysemityzm ${ }^{58}$. Należałoby też zadać pytanie, po co właściwie niemiecki fotograf wykonał

${ }^{58}$ M. Majewski, P. Reszka, Tajemnica zdjęcia $z$ Treblinki, „Rzeczpospolita”, 28 II 2011, archiwum.rp.pl/artykul/1026823-Tajemnica-zdjecia-z-Treblinki.html (dostęp: 29 XII 2017). 
zdjęcia w Radomiu? Czy nie w celach propagandowych? Cóż, chłopi, którzy byli (i pewnie nadal sa) wielką niemową historii, już nam o tym nie powiedza, bo nie żyja, a dzienników i pamiętników nie pisali, o wywiady też ich nikt nie prosił. Można zatem tej niemowie przypisać wszystko - i tak nie zaprzeczy ${ }^{59}$.

Łukasz Krzyżanowski stawia kolejna, daleko idąca tezę: „Konfiskata, zaprowadzenie zarządu powierniczego nad mieniem polskich Żydów przez władze okupacyjne oraz przewłaszczenia z okresu wojny stanowiły początek procesu przejścia majątków żydowskich w ręce nieżydowskie. Proces ten w Polsce nie skończył się wraz II wojną światowa. W nowej, powojennej rzeczywistości był kontynuowany aż do późnych lat czterdziestych. W 1945 r. żydowskie nieruchomości oraz ta część mienia ruchomego, której nie wywieziono z Polski, znalazły się w zarządzie polskiego państwa lub osób prywatnych - Polaków" (s. 270-271). To z kolei prowadzi go do wniosku - przejętego zapewne od Ledera - że „wojna była rewolucją" (s. 272).

${ }^{59}$ Punktem odniesienia mógłby tu być ponownie dziennik Zygmunta Klukowskiego. Z jego zapisków wyłania się następujący ciąg zdarzeń (w Szczebrzeszynie): przejęcie mienia pożydowskiego organizował ustanowiony przez Niemców magistrat (,woźni z magistratu”, zapiski z 8 i 11 VIII 1942); zwerbowani lub wyznaczeni przez magistrat chłopi zwozili mienie pożydowskie do „hali targowej” (zapiski z 24 i 29 X 1942); niemieckie władze okupacyjne napominały z pomocą ulicznych megafonów, że „za przechowywanie Żydów lub ich rzeczy grozi kara śmierci" (zapisek z 21 X 1942); przewożeniu mienia pożydowskiego towarzyszył rabunek dokonywany przez część Polaków (zapiski z 22, 24, 26 X 1942); za ostentacyjne rabowanie mienia pożydowskiego niemieccy żandarmi karali śmiercią (zapiski z 26 i $27 \mathrm{X}$ 1942); część pożydowskich rzeczy (bielizna, sprzęty gospodarskie) Niemcy rozdysponowali do instytucji publicznych, jak np. szpital (zapisek z 29 X 1942); równolegle z przejmowaniem mienia pożydowskiego miało miejsce rekwirowanie przez Niemców wartościowszych rzeczy z polskich domów (zapisek z 30 X 1942). 29 X 1942 r. Klukowski zanotował: „Furmanki wciąż zwożą do hali żydowskie rzeczy. Już nie mieszczą się wewnątrz budynku i na rynku koło hali urosła olbrzymia góra z tych gratów”. Nie wiadomo, co się stało z tymi rzeczami; przypuszczalnie zostały wywiezione przez Niemców lub uległy zniszczeniu. W przypadku mieszkań pożydowskich zwraca uwagę zapisek Klukowskiego z 22 X 1942 r. o ich „opieczętowaniu” przez władze okupacyjne, a zwłaszcza zapisek z 16 XI 1942: „Po zlikwidowaniu Żydów w Szczebrzeszynie niektórzy biedniejsi mieszkańcy Polacy otrzymali przydziały na mieszkania pożydowskie, popłacili za nie niewielkie czynsze w magistracie, doprowadzili do porządku, obielili, powstawiali okna, ponaprawiali piece itd. i jako tako w nich się urządzili. Naraz dziś rano obębniono na mieście, że do godziny dwunastej w południe wszystkie te mieszkania mają być opróżnione. Na razie nie możemy się dowiedzieć, co to ma znaczyć”. Dziennik Klukowskiego, mimo wzmianek o kradzieżach dokonywanych przez część Polaków, nie pozostawia wątpliwości, że zdecydowaną większość mienia pożydowskiego przejęli Niemcy, a nie Polacy. Ważny jest też kontekst: brutalny terror skutkujący zobojętnieniem na śmierć i grabież. Przykładowo 20 VIII 1942 r. Klukowski pisał: „Rzadko przyjdzie dzień, żeby nie zastrzelono kilku Żydów. Ludzie tak do tego przywykli, że już nie przejmują się tym, jak przedtem. Strzały w nocy nie robią już takiego wrażenia. Prawie codziennie rozstrzeliwano i po jednym Polaku”. Zwracał też uwagę, że „niektórzy zaczynaja się już załamywać psychicznie” (zapisek z 19 IX 1942). Skutkowało to m.in. zachwianiem elementarnych norm społecznych. 
Trzeba przyznać, że Krzyżanowski stara się dość uważnie prześledzić powojenne prawodawstwo dotyczace restytucji mienia. Ciekawie wypada refleksja nad rolą aferzystów zajmujących się odzyskiwaniem mienia pożydowskiego, przy czym, jak się okazuje, byli wśród nich także członkowie Komitetu Żydowskiego w Radomiu (s. 307). Krzyżanowski zwraca celnie uwagę na komplikacje prawne wytworzone wskutek okupacji niemieckiej. Uwzględnia też skutki Ustawy z dnia 3 stycznia 1946 r. o przejęciu na własność Państwa podstawowych gałęzi gospodarki narodowej. Dochodzi wreszcie do wniosku, że „państwo uwłaszczyło się na mieniu swoich żydowskich obywateli” (s. 309). $\mathrm{Z}$ innych partii książki wynika, że nie budziło to sprzeciwu, gdyż w kwestii „przewłaszczenia” (jak to określa Krzyżanowski) wytworzyła się specyficzna zmowa milczenia.

Stwierdzenie, że „państwo uwłaszczyło się na mieniu swoich żydowskich obywateli”, należałoby opatrzeć informacją, że państwo nie tyle „uwłaszczyło się", ile zastosowało powszechnie obowiązująca normę prawa cywilnego, według której to Skarb Państwa jest spadkobiercą w przypadku braku spadkobierców bezpośrednich (art. 935 Kodeksu cywilnego). A jeśli już mowa o „uwłaszczeniu się", to warto by zastanowić się nad generalnym problemem zmian własnościowych dokonanych przez reżim komunistyczny.

Z obrazu nakreślonego przez Krzyżanowskiego niemal całkowicie znikną problem zniszczeń wojennych. Niezorientowany czytelnik może odnieść wrażenie, że do 1945 r. polskie miasta, miasteczka i wsie przetrwały w stanie niemal nienaruszonym, a ich mieszkańcy wzbogacili się jeszcze o mienie pożydowskie. Na temat skali zniszczeń spowodowanych na ziemiach polskich wskutek II wojny światowej napisano już tak wiele, że ustalenie podstawowych faktów nie nastręcza trudności. Krzyżanowski woli jednak pisać o Zamojszczyźnie, nie wspominając o akcji wysiedleńczej czy zapominając, że - nie licząc może Krakowa - wszystkie większe polskie ośrodki zostały albo zniszczone w kilkunastu bądź kilkudziesięciu procentach, albo utracone wraz z przesunięciem granicy polsko-sowieckiej na zachód.

Jednostronność ujęcia tematu przez Krzyżanowskiego wynika też z doboru lektur czy raczej ich niedoboru. Przykładem pominięty zbiór reportaży Barbary Stanisławczyk, pt. Czterdzieści twardych. Nie jest to błaha książka. Znawca zagadnienia, Sławomir Buryła, pisał w 2009 r.: „Pośród książek, które mam za soba jako badacz problematyki Holocaustu, doprawdy nie mógłbym wymienić zbyt wiele takich, które wywarły na mnie równie mocne wrażenie jak Czterdzieści twardych. Reportaże Stanisławczyk są dziełem z najwyższej półki" ${ }^{60}$. W tej doniosłej książce znajdujemy też reportaż o rodzinie Rottenbergów z Radomia. Skoro nie zrobił tego Krzyżanowski, przypomnijmy tu pokrótce jego treść. Właściwie jest to historia dwóch rodzin: polskiej

${ }^{60}$ S. Buryła, Gorzkie prawdy. O ksiażce Barbary Stanistawczyk „Czterdzieści twardych”, „Znak” 2009, nr 6, www.miesiecznik.znak.com.pl (dostęp: 7 XII 2017). 
Czupryniaków i żydowskiej Rottenbergów, których losy splotły się w czasie wojny. Czupryniakowie, najpierw ojciec Władysław, potem jego syn Janusz pracowali w Biurze Techniczno-Handlowym W. Siwecki przy ul. Żurawiej 6 w Warszawie. Dla Janusza Czupryniaka posada ta była też przykrywką dla jego działalności w ZWZ/AK. Po sąsiedzku siedzibę miało biuro radomskiej fabryki porcelany. Jej właściciel, Marian Rottenberg, po wybuchu wojny uciekł wraz z żoną do Lwowa. Po kampanii wrześniowej Rottenbergowie wrócili jednak do Warszawy. Niebawem znaleźli się w getcie. Pragnąc ratować siebie i żonę, Marian Rottenberg zwrócił się do Władysława Czupryniaka o pomoc. Czupryniakowie - Władysław, jego żona Irena i ich syn Janusz - odbyli rodzinną naradę i przystapili do działania. Znajomy młynarz zamieszkały na wsi pod Mszczonowem gotów był przyjąc Rottenbergów do siebie, ale pod warunkiem, że sami się utrzymaja, wskutek okupacji utracił bowiem dochody i nie miał już za co wyżywić nawet własnej rodziny (mógłby to być przyczynek do powtarzanych przez Krzyżanowskiego w ślad za Janem Grabowskim zarzutów wobec Polaków o ratowanie Żydów tylko za pieniądze). Rottenbergowie mieli wprawdzie dość pieniędzy, ale zabrała im wszystko co do grosza policja żydowska w zamian za przepuszczenie z getta na „stronę aryjską; ocalał tylko pierścionek na palcu żony Mariana, którego żydowscy policjanci nie zdołali ściagnać. Jeden ze znajomych Czupryniaków, który zgodził się przenocować Rottenbergów, wycofał się, gdyż przestraszył się konsekwencji (przypomnijmy, że za pomoc Żydom Niemcy karali śmiercia). Udało się w końcu ulokować Rottenbergów w mieszkaniu na rogu Chmielnej i Zgody, którego właścicielka świadczyła własnym ciałem usługi pewnemu kapitanowi Wehrmachtu, a kilka pokoi odstępowała AK na cele konspiracyjne. Gdy kochankowie się pokłócili, Rottenbergów trzeba było ewakuować. Czupryniakowie postanowili wtedy ukryć ich w swoim domu w Ursusie pod Warszawa. Dotrwali tu do stycznia 1945 r. Jak im się to udało, dowiemy się od Stanisławczyk. Janusz Czupryniak walczył w Powstaniu Warszawskim w pułku „Baszta”, został ciężko ranny, trafił do niemieckiej niewoli, wrócił do kraju skrajnie wyczerpany, zmarłby niechybnie, gdyby nie penicylina. Niebawem musiał uciekać, gdyż polowanie na niego urządziło UB. Rottenbergowie powrócili tymczasem do Radomia.

I ten właśnie epizod warto przybliżyć, rzuca on bowiem inne światło na powojenne stosunki w tym mieście, niż to przedstawia Krzyżanowski. Fabryka porcelany Rottenberga zarządzała już nowa administracja miasta. Wbrew twierdzeniom Krzyżanowskiego o „morzu nienawiści” okazuje się, że robotnicy powitali życzliwie powrót prawowitego właściciela i to dzięki ich poparciu Marian Rottenberg został przynajmniej dyrektorem swojej dawnej fabryki. Wytaczał procesy rewindykacyjne i je wygrywał, a domy, które odzyskał, sprzedał. Zwrot nastapił w roku 1948. „Wiceminister przemysłu, z pochodzenia Żyd, ostentacyjnie ogłosił Marianowi swój wyrok: «Możesz sobie, Rottenberg, wygrywać procesy, a od nas i tak dostaniesz gówno»". W ramach 
rekompensaty Marian Rottenberg otrzymał posadę w Ministerstwie Przemysłu, gdzie miał nadzorować upaństwowiona produkcję wyrobów porcelanowych. Komunistyczna „walka klasowa” uderzyła zatem rykoszetem również w rodzinę Rottenbergów, co pokazuje zwodniczość określenia „żydokomuna”. Ale tę „walkę klasową" prowadziło w pierwszej kolejności Ministerstwo Przemysłu, kierowane przez Hilarego Minca, architekta planu sześcioletniego, $\mathrm{w}$ największej mierze odpowiedzialnego za zmiany własnościowe w Polsce. Nazwisko Minca również nie pojawia się w książe Krzyżanowskiego. Tymczasem już wiele lat temu Andrzej Wróblewski, daleki od zamazywania przewin Polaków, zwracał uwagę, że kierownictwo Ministerstwa Przemysłu na czele z jego szefem tworzyły osoby pochodzenia żydowskiego, co skłaniało go do postawienia pytania zarówno o rolę żydowskich komunistów w powojennej Polsce, jak i o wpływ ich działań na zjawisko antysemityzmu ${ }^{61}$.

Puenta reportażu Stanisławczyk też daje do myślenia. Role się odwróciły. Po wojnie to Rottenbergowie pomogli Januszowi Czupryniakowi się ukrywać, najpierw w Radomiu, potem w Kaliszu. W końcu Czupryniak został aresztowany pod pretekstem nielegalnego handlu i w trybie doraźnym skazany na sześć lat więzienia. Rottenbergowie zaś po kilku latach wyjechali do Niemiec, gdzie otrzymali odszkodowanie, potem przenieśli się do Izraela, ale nie mogąc się tam zaaklimatyzować, wyemigrowali do Australii. Czupryniak otrzymał pod koniec lat osiemdziesiątych XX w. medal „Sprawiedliwy wśród Narodów Świata”, ale wcześniej przeżył szok po obejrzeniu filmu Shoah Claude’a Lanzmanna; protestował nawet w redakcji „Fołks-Sztyme”. Pod koniec życia napominał: „Trzeba mówić dokładnie. Był Auschwitz, a nie Oświęcim. Birkenau, a nie Brzezinka... I tak dalej. Historia nie jest potoczna, jest precyzyjna. I szczegół może ją odwrócić o 180 stopni”"62.

Zamiast szczegółów Krzyżanowski ostatecznie wybiera generalizację. Zakończenie książki przypomina moralitet, który przemienia się w akt oskarżenia pod adresem ogółu Polaków - w konwencji Grossa i Ledera. „W wyniku dokonanego na niewyobrażalną skalę przewłaszczenia mienia polskich Żydów

${ }^{61}$ Wróblewski stawiał też następujące pytanie: „Sztab Minca, jego otoczenie składało się w większości z ludzi pochodzenia żydowskiego. Jednym z jego wiceministrów był pan, którego rozpoznano jako syna jakiegoś wielkiego przedsiębiorcy z Sosnowca. Należał formalnie nie do PPR, lecz do Stronnictwa Demokratycznego, był oddelegowany do demokratów, jak wówczas mówiono. Być może jego fabrykanckie doświadczenie stanowiło gwarancję kompetencji, ale przedwojennych przemysłowców, menadżerów big businessu, niekoniecznie Żydów, było w Polsce więcej. Wciagnięci do przemysłu, realizowaliby narzucone im zadania z równa, jeśli nie wyższą znajomością rzeczy. Dlaczego człowiekiem zaufania mógł zostać syn wielkiego przemysłowca i dygnitarza sanacyjnego Wacława Wiślickiego, Żyda, a odmawiano tego zaufania przedwojennemu dyrektorowi Zakładów Starachowickich? Złośliwi odpowiadali ironicznie: decydowało nie pochodzenie klasowe, lecz rasowe”. A. Wróblewski, Być Żydem... Rozmowa z Dagiem Halvorsenem o Żydach i antysemityzmie Polaków, Warszawa 1993, s. 166.

${ }^{62}$ B. Stanisławczyk, Czterdzieści twardych, Łódź 1997, s. 235-259. 
stało się mieniem "pożydowskim» pozostającym pod kontrolą państwa polskiego lub jego nieżydowskich obywateli” (s. 315). Należy ponowić apel, by tego rodzaju oskarżenia, czyniące z Polaków brudną wspólnotę złodziei, formułować z najwyższą ostrożnością i z uwzględnieniem realiów historycznych. Paradoksalnie, rozpisując się o „przewłaszczeniu na niewyobrażalną skalę”, Krzyżanowski mimowolnie powiela antysemicką kliszę żydowskiego bogactwa. Znaczną część społeczności żydowskiej przed wojną stanowiła przecież biedota. Jeśli przejmowano coś po Żydach, to siłą rzeczy - żydowską biedę ${ }^{63}$. Nawet jeśli owe furmanki sfotografowane przez niemieckiego fotografa w Radomiu w 1942 r. zajechać miały do chłopskich chat (a pewności nie ma), to to, co na nich widać, świadczy raczej o ubóstwie niż bogactwie. Jeśli jacyś chłopi stali się posiadaczami tych starych mebli i garnków, co oczywiście z dzisiejszej perspektywy może budzić etyczny sprzeciw, to awansu społecznego dzięki temu nie uzyskali. O tym, że korzyści materialne z zagłady Żydów „odnosiła niewielka, bądź co bądź, grupa ludności polskiej”, pisała przed laty Teresa Prekerowa ${ }^{64}$. O skali dewastacji zwłaszcza małych miast i miasteczek oraz zubożenia ich mieszkańców - wskutek wojny, a następnie „bitwy o handel”, zniszczenia prywatnej przedsiębiorczości, zaniechania inwestycji w infrastrukturę - wiele dowiemy się z książki Jerzego Kochanowskiego Rewolucja międzypaździernikowa ${ }^{65}$.

Łukasz Krzyżanowski jest obecnie pracownikiem Instytutu Wschodnioeuropejskiego Wolnego Uniwersytetu Berlińskiego. Prowadzi zajęcia pt. „Yiddishland in der Nachkriegszeit” (,Kraj jidysz w okresie powojennym”), które dotyczą zapewne szeroko rozumianej Europy Środkowo-Wschodniej. Trzeba pogratulować młodemu badaczowi międzynarodowej kariery; niewielu to potrafi. Jednak trudno się nie zadumać nad obrazem powojennej Polski, przekazywanym przez Krzyżanowskiego niemieckim studentom. Wkrótce omawiana tu książka ma się ukazać po angielsku nakładem Harvard University Press ${ }^{66}$. Światowa opinia publiczna dowie się o okupowanym Radomiu bez Gestapo i Paula Fuchsa, o Zamojszczyźnie bez wysiedleń, o Polsce bez zniszczeń i strat ludzkich, za to „niewyobrażalnie” wzbogaconej za sprawa „prześnionej rewolucji”.

Szkoda tej książki. Łukasz Krzyżanowski ujawnił przecież talent reportera historycznego, niemałą wrażliwość i empatię, pasję badawczą. Napisał jednak książkę skrajnie jednostronną - niemal całkowicie pod dyktando Grossa.

${ }^{63}$ Zygmunt Klukowski zanotował 26 X 1942: „ludzie bezwstydnie dźwigają całe toboły z nędznym żydowskim dobytkiem lub towarem z małych sklepików”. Z. Klukowski, op. cit., s. 306.

${ }^{64}$ T. Prekerowa, op. cit., s. 306.

${ }^{65}$ J. Kochanowski, Rewolucja międzypaździernikowa. Polska 1956-1957, Kraków 2017, s. $131-137,330$.

${ }^{66}$ Książka jest już reklamowana jako „a mature work of non-fiction and a reliable testimony of scholarly honesty in searching for the truth", www.en.nurnberg.pl/2017/08/30/ lukasz-krzyzanowskis-ghost-citizens-sold-to-harvard-university-press (dostęp: 12 III 2018). 
Pogardzany przez Autora Prymas Wyszyński mawiał: „intelektualista tym różni się od inteligenta, że intelektualista używa swojego rozumu, a inteligent cudzego"67. Chciałoby się, by Krzyżanowski odłożył swoistą twórczość Grossa (czy epigońskiego Ledera) gdzieś głęboko na półkę i napisał tę książkę raz jeszcze, samodzielnie i nonkonformistycznie. Marzyłoby się, by wybrzmiał w niej zarówno żydowski, jak i polski punkt widzenia; nie jest to niemożliwe, o czym świadczy cytowany wcześniej obszernie dziennik Mariana Brandysa. By było w niej miejsce na refleksję socjologiczną i rzetelną analizę historyczna. Taka książka stałaby się dziełem naprawdę wybitnym.

${ }^{67}$ Cyt. za: Kościót, Żydzi, Polska. Z księdzem profesorem Waldemarem Chrostowskim rozmawiaja: Grzegorz Górny i Rafat Tichy, Warszawa 2009, s. 250. 